\title{
Cyclin-Dependent Kinase 6
}

National Cancer Institute

\section{Source}

National Cancer Institute. Cyclin-Dependent Kinase 6. NCI Thesaurus. Code C97386.

Cyclin-dependent kinase 6 (326 aa, $\sim 37 \mathrm{kDa}$ ) is encoded by the human CDK6 gene. This protein plays a role in both protein phosphorylation and cell cycle progression. 